\title{
Inadequate supply of fuelwood and timber from forests of Nepal
}

\author{
Raj Bahadur Shrestha ${ }^{1}$
}

\begin{abstract}
The existing public supply of fuelwood does not meet the demand of growing population. While peoples' need of fuelwood is being met mostly from government forests legally or illegally, and some from community and private lands, the government will soon find it difficult to compensate $69 \%$ of fuelwood energy from the depleting forest. Appropriate technologies such as biogass, improved stoves, etc. should be promoted to reduce fuelwood consumption. Also, appropriate harvesting technology could help improve fuelwood and timber supply system of the country.
\end{abstract}

Keywords: Demand and supply, fuelwood, timber, Nepal.

T Nepal, fuelwood, agriculture residues, and animal wastes form the traditional sources of energy whereas coal, kerosene, and electricity are the commercial ones. The energy from hydropower, biogass, LPG (cooking gases), and solar are considered far from the reach of the general public. The traditional sources supply nearly ninty two percent of energy (biomass 69\%; agriculture residues $15 \%$ and animal wastes $8 \%$ ) (REDP, 1997).

Fuelwood is still the main source of cooking and heating especially in rural areas. Rural residents use about $70 \%$ of fuelwood as compared to urban who use 31\% (Adhikari, 1999). The demand of such products is obviously high in compare to the supply. The present paper therefore, discusses on demand-supply system of fuelwood for household consumption in Nepal. It is based on the author's field experience and literature search. Few recommendations which are expected to correct the supply system have been presented.

\section{Existing demand-supply system}

The actual demand-supply situation of fuewood is difficult to quantify due to lack of valid figures. There is no nation-wide studies. The only official estimatation for per-capita household consumption of fuelwood for the urban area is $248 \mathrm{~kg}$ and for rural areas (including mountain and Terai) is $559 \mathrm{~kg}$ (HMG, 1988). Based on such data and alongwith the existing population growth rate, the present demand of fuelwood has been presented in Table 1.

Similarly, the actual supply of fuelwood only from the government-managed forests has also been tabulated. Likewise, for comparison HMG's projection for the year 1995/96 has been also presented.
As per the Forest Act (1993), Timber Corporation of Nepal (TCN), District Forest Supply Board (DFSB), and District Forest Office (DFO) are involved in supplying timber and fuelwood. The former supplies fuelwood generally to the city dwellers and to industries. DFSB which has been formed in twenty six districts, supplies fuelwood upon demand by the local people. Similarly, DFOs of the remaining districts allow the people to collect fuelwood from the government forests, if asked permission.

\section{Status of forest}

Forest areas are decreasing annually. In 1963/64, the forest cover was $45.6 \%$ of the total land (HMG/USAID, 1963/64; cited in FRISP, 1998), which was $38 \%$ in $1978 / 79$ (LRMP 1986). Now, it has gone down to $29 \%$ of the total land area (DFRS 1999). Apart from that, this figure also includes protected forests which cover $18.84 \%$ of the total land. The forest cover is decreasing with a rate of

1. 7 percent each year. The hilly area has high rate $(2.3 \%)$ whereas it is $1.3 \%$ in the Terai. The physiographical distribution of the forest cover is shown in the Table 2 .

\section{Discussions and recommendations}

Despite there are alternative sources, rural Nepali still need fuelwood for cooking and heating. Therefore, demand for fuelwood is high. The supply by the government of lacking far behind (see fig 1).

For the last few years, a slight change in the pattern of demand in the urban areas like Kathmandu, Biratnagar, Pokhara, etc. has occurred. 
Shrestha

Banko Janakari, Vol. 9, No. 2

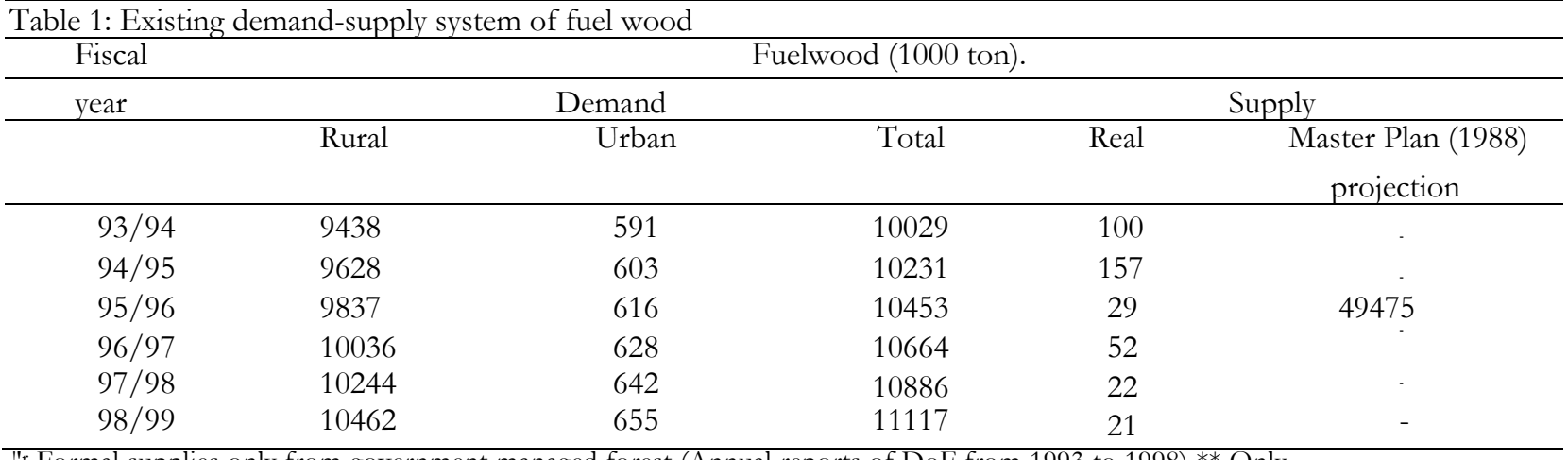

!'r Formal supplies only from government managed forest (Annual reports of DoF from 1993 to 1998) ** Only from forests

Demand for fuelwood has rapidly decreased in these areas, due to alternative sources and changing life style of the urban people.) The use of LPG and Kerosene has reduced fuelwood consumption in Kathmandu valley by $50 \%$ in 1989/90 with compared to 1984/85 (Adhikari 1999). However, this has not minimised the fuelwood consumption in developing urban towns like Chitwan, Surkhet, Illam, and so on. Villagers are still seen selling fuelwood in these places.

Table 2: $\quad$ Distribution of tree cover by physiographical zones.

\begin{tabular}{lr}
\hline \multicolumn{1}{c}{ Physiographic regions } & Area of forests $(\%)$ \\
\hline High Himal & 2.75 \\
High Mountains & 29.68 \\
Mid Mountains & 27.11 \\
Shiwalik & 29.25 \\
Terai & 11.21 \\
\hline Total & 29 \\
\hline
\end{tabular}

In rural areas, no such institution exists for selling fuelwood to the rural people. Nor the rural people can afford to buy other alternative sources. This makes clear that forests are the only option for them to get fuelwood. This is either with the permission of DFO or Community Forest (CF) or from private owners (PO) or others. The supply from DFO is negligible and that from CF and PO is very less because contribution of CF, PL, and others is 11. $9 \%, 18.95 \%$, and $3.09 \%$, respectively (CBS, 1996a; cited at Adhikari, 1999). The question then arises how the people have been managing their need for fuelwood ? The simple answer is that they have been collecting it from government managed forests without permission. Contribution of government forest in supplying fuelwood which is $66.06 \%$ (CBS, 1996a; cited at Adhikari, 1999), also proves this.

The main problem for the future is that the growing population has to depend on limited as well as ep eting forest resources (fig 2). Similarly, supply rom High. Himal region is virtually impossible, iwa $\mathrm{i}$ region is fragile and is not recommended to harvest trees. The Terai and mountain forests are the only potential areas from where timber and fuelwood can be harvested, but meeting the demand only from these areas is unattainable. In addition, the Terai and mountain forests also include protected forests - the exploitation of which is out of question. Also, there has been no scientific management of commercial forests, the deficit will continue to rise, and the vicious cycle continues.

Fig 1: Existing trend of demandsupply of fuelwood

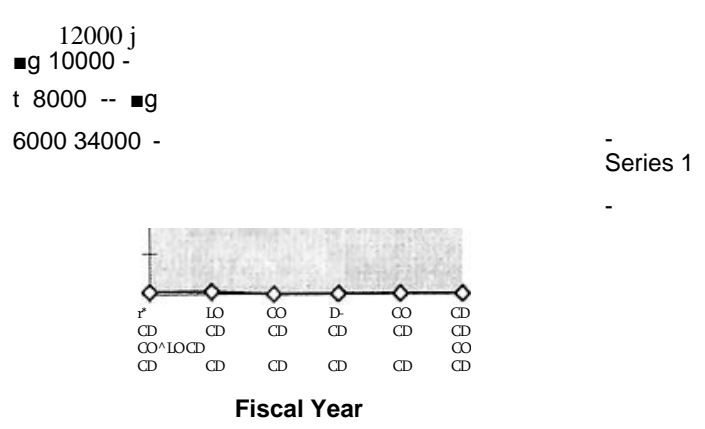

Fig 2: Physiographical distribution of forests

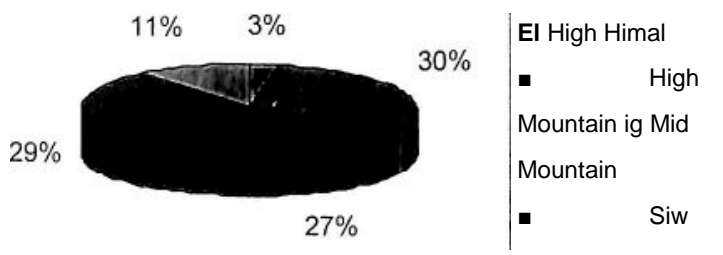

In such scenario, the following recommendations will, to some extent help manage the supply in relation to demand:

(R) Base line study on demand-supply situation and related matters should be done for planning. 
Banko Janakari, Vol. 9, No. 2

- The shrub land should be managed to expand the forest area.

- Effective-harvesting operations should be carried out in CFs with a sound technical plan.

- Involvement of private sectors in the forestry should be emphasised as a partner. Private forestry enhancement programmemes should be simultaneously carried in order to increase supply.

- Afforestation and reforestation programmes should be revitalised.

- Mountain forests should be also managed for harvest. Transportation through cable-logging system could be an option for mountains.

- Technically sound Operational Forest Management Plan should be developed and implemented.

- The Terai forests should be managed as a partnership between government and local communities.

- Dependency on fuelwood in rural areas should be minimised by promoting biogass and other domestic sources. Similarly, improved stove should again be encouraged to use.

\section{References}

Adhikari, D. V. 1999. A report on air pollution

\section{Shrestha}

situation and management plan, Kathmandu, Nepal.

DFRS 1999. Forest and shrub cover of Nepal 1994, Department of Forest Research and Survey Publication No 72, Kathmandu, Nepal.

DoF 1994. An introduction of Department of Forests, Department of Forest, Kathmandu, Nepal.

DoF 1999. Annual reports (1993 to 1997) of the Department of Forest, Kathmandu, Nepal.

FRISP 1998. Strategic guidelines for Forest utilization, Forest Resource Information System Project Main Report No 10, HMG/FINNIDA, Kathmandu, Nepal.

HMG 1998. Master Plan for Forestry Sector, Main Report, Ministry of Forest and Soil Conservation, Singhdarvar, Kathmandu, Nepal.

LRMP 1986. Land utilization report, Land Resource Mapping Project Kathmandu, Nepal.

REDP 1997. Environment Management Guideline, Rural Energy Development Program, NEP/95/016 Publication, Kathmandu, Nepal. 